\title{
MODELLING THE INFLUENCE OF NUCLEAR FUEL MICROSTRUCTURE ON FISSION PRODUCT RELEASE
}

\author{
G. Stankūnas ${ }^{a}$, G. Kamuntavičius ${ }^{\text {a }}$, L. Juodis ${ }^{b}$, G. Trinkūnas ${ }^{\mathrm{b}}$, and V. Remeikis ${ }^{\mathrm{b}}$ \\ ${ }^{a}$ Vytautas Magnus University, Faculty of Natural Sciences, Department of Physics, Vileikos 8, LT-44404 Kaunas, Lithuania \\ ${ }^{\mathrm{b}}$ Institute of Physics, Savanoriu 231, LT-02300 Vilnius, Lithuania \\ E-mail: laurynas@ar.fi.lt
}

Received 24 February 2006

\begin{abstract}
A model of the gaseous fission product release from the nuclear fuel pellet is proposed. The presence of fission product bubbles in the fuel matrix is simulated as periodical modulation of the diffusion coefficient by chain of Gaussian functions. The numerical solution of a diffusion equation shows enhanced fission product release at larger bubble concentrations. It is related to the facilitated diffusion of gaseous fission products in grain boundary bubbles of medium and higher burnup fuel ( $>30 \mathrm{MW} \mathrm{d} / \mathrm{kg} \mathrm{U}$ ). The calculated profile of the fission product concentration distribution is similar to that obtained in the experimental studies. It is demonstrated that the influence of the developed fuel microstructure on the gaseous fission product release can be equivalently taken into account by modifying the Arrhenius behaviour of the diffusion coefficient.
\end{abstract}

Keywords: nuclear fuel, fission products, diffusion, structure, modelling

PACS: 28.41.Bm, 66.30.Jt

\section{Introduction}

Deep understanding of the fission product (FP) release is essential for determining operational and safety characteristics of a nuclear reactor as well as the radioactive waste generation process in nuclear power plants. Knowledge of these processes could be efficiently used for radioactive waste characterization, such as the scaling factor estimation and application. In particular, this can be used to determine the concentrations of some difficult-to-measure radionuclides, such as ${ }^{129} \mathrm{I},{ }^{99} \mathrm{Tc},{ }^{239,}{ }^{240} \mathrm{Pu},{ }^{241} \mathrm{Am},{ }^{242,244} \mathrm{Cm},{ }^{55} \mathrm{Fe},{ }^{63} \mathrm{Ni}$, ${ }^{14} \mathrm{C},{ }^{90} \mathrm{Sr}$, etc., which is of primary importance in the radioactive waste management at nuclear power plants [1]. Moreover, the detailed knowledge of the FP release mechanism is essential for prediction of radionuclide releases during the operational stages of the reactor, postulated accidents or spent nuclear fuel storage and disposal [2]. FP release mechanisms are essential for the assessment of nuclear fuel burnup extension possibilities as well. On the other hand, understanding of the FP diffusion process in solids with a complex structure is a challenging problem. The release of FP from the matrix of nuclear fuel is considerably influenced by the structural formations, namely, FP bubbles in fuel grains and between them, and defects of $\mathrm{UO}_{2}$ matrix as well [1]. The influence of FP bubbles is ambivalent.
It is known that in general the bubbles in the low burnup fuel reduce the release rate of FP due to their trapping effect [2]. However, at medium and higher burnups ( $>30 \mathrm{MW} \mathrm{d} / \mathrm{kg} \mathrm{U})$, the coarse bubbles at grain boundaries build the porous structures which facilitate the FP release from the fuel pellets. We propose here to take into account the porous microstructure of the fuel by applying periodic modulation of the diffusion coefficient by chain of Gaussian functions and to show that enhanced diffusion can be rationalized by modifying the Arrhenius behaviour of the diffusion coefficient.

\section{Model of FP diffusion in nuclear fuel}

The nuclear fuel pellet composed of $\mathrm{UO}_{2}$ has a specific cylindrical form and internal microstructure predetermined by the production process. The $\mathrm{UO}_{2}$ grains in the fresh fuel are of the $6-10 \mu \mathrm{m}$ diameter $[2,3]$. Therefore, it is possible to build the following geometrical model of the fuel pellet for the FP release estimation.

A fuel pellet can be divided into separate cylinders. Then the cylinders can be divided by horizontal and radial planes resulting in a cube of a convex form. An average temperature gradient of $1.4 \cdot 10^{5} \mathrm{~K} / \mathrm{m}$ is observed in the fuel pellet during the reactor operation. Due to 


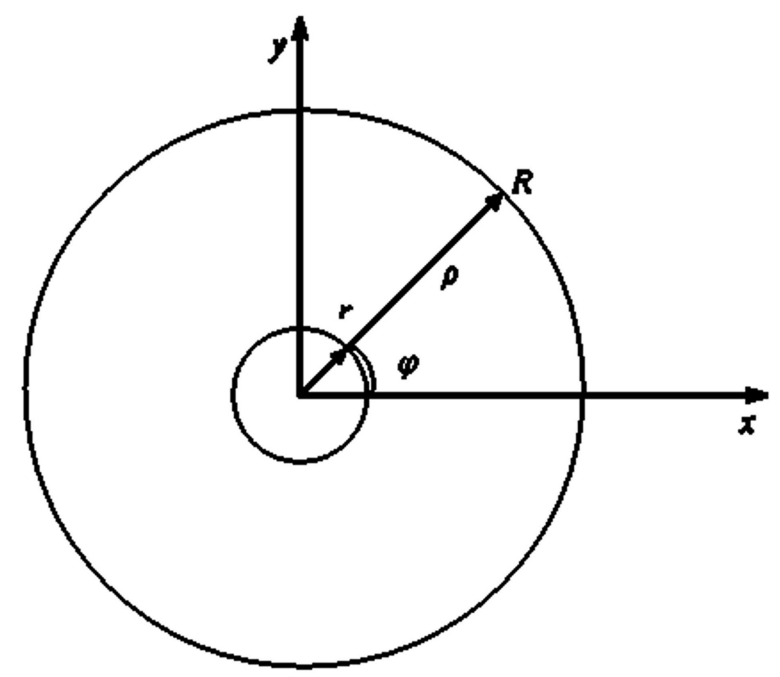

Fig. 1. Cross-section of the fuel pellet. $R$ and $r$ are the outer and inner pellet radii, respectively.

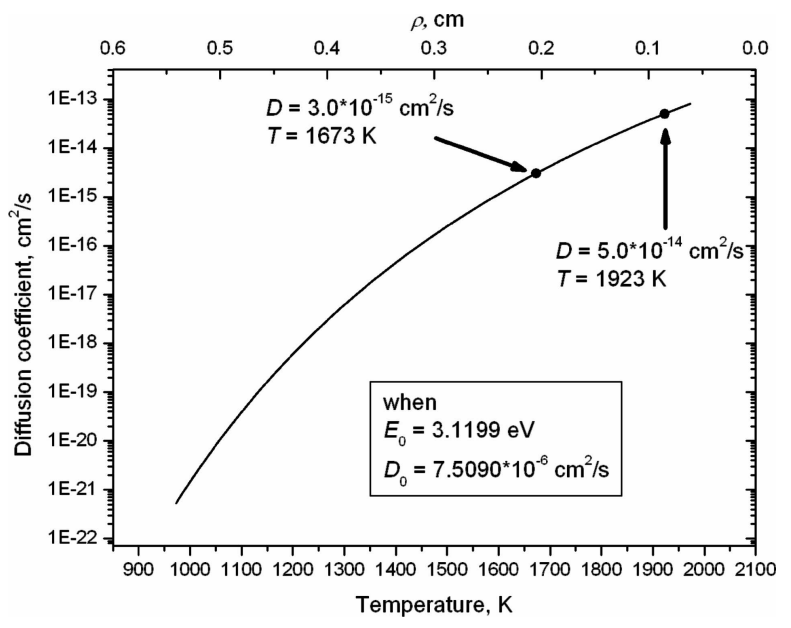

Fig. 2. Temperature dependence of the diffusion coefficient along the pellet radius.

this fact we simplify the description of the diffusion process to the $1 \mathrm{D}$ problem just taking a radial component into account in the mathematical model of FP diffusion.

A widely used approach is to apply the so-called effective diffusion coefficient defined simply as an empirical function of temperature and the fission rate [4]. It is well accepted that the main mechanism of the FP release from the sintered fuel is the gas atom diffusion to grain boundaries and from there to the free volume of the rod by venting through porous grain boundary structures [5]. This model of the gas release results in a complex set of differential equations. On the other hand, the characteristic size of fuel grains and inhomogeneities in fuel rods are very small in comparison with the pellet size, so the large-scale description of this pro- cess as ordinary diffusion can help us to understand the whole problem [6].

We consider a simple model of FP diffusion in sintered $\mathrm{UO}_{2}$ pellets or rods, the most common fuel type in light water reactors. Both of them have cylindrical symmetry and the gas atom concentration is assumed to be uniform along the rod, hence independent of the third cylindrical coordinate $z$ and cylindrical angle $\varphi$ (Fig. 1).

Referring to our previous study [6] we present here just the final form of the diffusion equation for the release of some FP concentration $c$ from the nuclear fuel pellet characterized by diffusion coefficient $D(\rho)$ :

$\frac{\partial c(\rho, t)}{\partial t}=\frac{1}{\rho} \frac{\partial}{\partial \rho}\left(\rho D(\rho) \frac{\partial c(\rho, t)}{\partial \rho}\right)-\lambda c(\rho, t)+g(t)$,

where $\lambda$ is the FP decay rate and $g$ is the FP generation rate. We express the dependence of the diffusion coefficient on fuel temperature $T$ by the usual Arrhenius form:

$$
D(\rho)=D(T(\rho))=D_{0} \exp \left(-\frac{E}{k T(\rho)}\right)
$$

and by taking into account the experimental dependence of temperature on a radial variable $\rho$, i. e., $T(\rho)$, we obtain its dependence on $\rho$ [7].

Equation (1) holds for the fuel pellet region $r \leq \rho \leq$ $R$ with the following radiation boundary conditions:

$$
\begin{aligned}
& {\left[D(\rho) \frac{\partial c(\rho, t)}{\partial \rho}-b c(\rho, t)\right]_{\rho=r}=0} \\
& {\left[D(\rho) \frac{\partial c(\rho, t)}{\partial \rho}-b c(\rho, t)\right]_{\rho=R}=0}
\end{aligned}
$$

where $b$ stands for the gaseous FP leakage rate, $r$ and $R$ correspond to the inner and outer radii of the fuel pellet, respectively. Boundary conditions indicate that FP particles leak out through the boundaries $r$ and $R$ of the fuel pellet all the time and the flux is proportional to the concentration of particles at the boundary.

In our further analysis and calculations we use dimensionless form of Eq. (1) and its boundary conditions Eq. (3). We express the variable length $\rho$, time $t$ and concentration $c$ by dimensionless variables $z, \tau$, and $n$ as follows:

$$
\rho=\sqrt{\frac{D_{0}}{\lambda} \cdot z}, \quad t=\frac{1}{\lambda} \cdot \tau, \quad c=\frac{1}{\left(\sqrt{\frac{D_{0}}{\lambda}}\right)^{3}} \cdot n .
$$




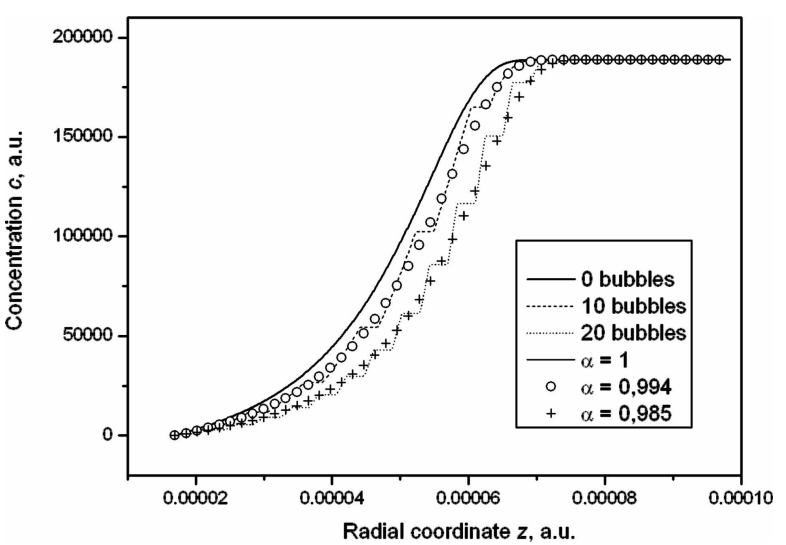

Fig. 3. Quasi-stationary concentration distribution of FP along the pellet radius for different number of peaks of modulating function in Eq. (6). Peak width parameter $0.25 \cdot 10^{-6}$ is used.

The main diffusion equation with the new variables:

$$
\frac{\partial n(z, \tau)}{\partial \tau}=\frac{1}{z} \frac{\partial}{\partial z}\left(z \frac{D(z)}{D_{0}} \frac{\partial n(z, \tau)}{\partial z}\right)-n+\gamma,
$$

here we use the dimensionless parameter $\gamma$ of isotope generation expressed as $\gamma=\left(D_{0} / \lambda\right)^{3 / 2} \cdot \lambda^{-1} \cdot g$. The leakage rate $b$ of gaseous FP is expressed by the dimensionless variable $\beta$ as follows: $\beta=b\left(D_{0} \lambda\right)^{-1 / 2}$. As a result we get the following dimensionless boundary conditions of diffusion Eq. (4):

$$
\begin{aligned}
& {\left[\frac{D}{D_{0}} \frac{\partial n(z, \tau)}{\partial z}-\beta n=0\right]_{z(r)},} \\
& {\left[\frac{D}{D_{0}} \frac{\partial n(z, \tau)}{\partial z}+\beta n=0\right]_{z(R)},}
\end{aligned}
$$

where $z(r)=r \sqrt{\lambda / D_{0}}$ and $z(R)=R \sqrt{\lambda / D_{0}}$.

Referring to the experimental measurements, we applied two values of the diffusion coefficient at different temperatures for iodine in $\mathrm{UO}_{2}$, i.e.: (i) $\sim 5 \cdot 10^{-14} \mathrm{~cm}^{2} / \mathrm{s}$ at $1923 \mathrm{~K}$ and (ii) $3 \cdot 10^{-15} \mathrm{~cm}^{2} / \mathrm{s}$ at $1673 \mathrm{~K}$ [7]. Then, having inserted these two values into Eq. (2) we calculated values of $E_{0}=3.12 \mathrm{eV}$ and $D_{0}=7.5 \cdot 10^{-6} \mathrm{~cm}^{2} / \mathrm{s}$, respectively. Further calculations were performed using these values. The dependence of the diffusion coefficient on the $\mathrm{UO}_{2}$ temperature is presented in Fig. 2.

\section{Simulation results}

The release of FP from the nuclear fuel is greatly influenced by the fuel microstructure, in particular by the FP bubbles. Four phases of the structure, namely, the fuel matrix $\left(\mathrm{UO}_{2}\right)$, intragranular bubbles, bubbles at the grain boundaries, and open grain boundary bubbles

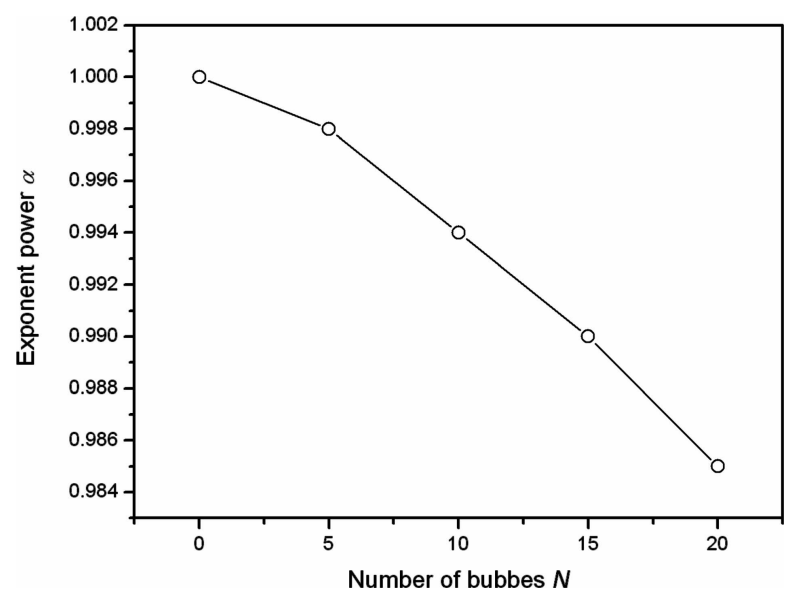

Fig. 4. Dependence of the exponent power $\alpha$ on the number of bubbles along the pellet radius.

affect the diffusive release of FP to the void space between the pellets and fuel cladding [2, 4, 8]. It is known from experiments that porosity at grain boundaries of high burnup fuel acts like structures facilitating the FP release [2-5]. The grain boundary bubbles grow, they can interconnect and form the tunnels resulting in the FP release to the fuel-to-clad gap. The gaseous FP, such as noble gases, iodine, or cesium, can be very mobile in these pores. We propose to take into account coarse intergranular bubbles formed at high burnups by the periodical modulation function of the diffusion coefficient as follows:

$$
\begin{aligned}
D= & D_{0}\left(1+\frac{1}{\sqrt{2 \pi \sigma^{2}}} \sum_{i=1}^{N} \exp \left\{-\frac{\left(z-z_{i}\right)^{2}}{2 \sigma^{2}}\right\}\right) \\
& \times \exp \left\{-\frac{E_{0}}{k_{B} T}\right\},
\end{aligned}
$$

where $\sigma$ is the parameter corresponding to the intergranular bubble radius, $z_{i}$ is the bubble site position, $N$ is the number of bubbles. The maximum positions of $D$ indicate the location of grain boundary bubbles representing the increased diffusion of mobile FP.

The FP concentration profiles of quasi-stationary state in the pellet are obtained by numerically solving Eq. (1). The different number of bubbles represented as peaks in the modulating function of the diffusion coefficient was applied in order to show the influence of the bubble concentration on the FP migration in the fuel pellet. We show that the migration of FP is faster if more grain boundary bubbles are present along the pellet radius. This qualitatively agrees well with experimental observations of the FP release from the high burnup fuel $[2,3]$. With increasing burnup the grain boundary porosity of the fuel increases due to the 
formed routes for the FP release to the fuel-to-clad gap. Comparison of FP concentration distributions across the pellet radius calculated with diffusion coefficients expressed by Eqs. (6) and (7) is depicted in Fig. 3. One can clearly see the enhanced FP diffusion to the pellet boundary at higher bubble concentrations.

Finally, we have found that the FP distribution profiles obtained with the modulated diffusion coefficient (Eq. (6)) can be equivalently reproduced by solution of Eqs. (1)-(3) with the diffusion coefficient involving the modified temperature dependence:

$$
D=D_{0} \exp \left\{-\left(\frac{E_{0}}{k T}\right)^{\alpha}\right\}
$$

Having applied the modified Arrhenius relation (Eq. (7)) we have determined the dependence of the exponent power $\alpha$ on the number of bubbles along the pellet radius depicted in Fig. 4. The fuel microstructure with the spatially modulated diffusion coefficient along the fuel pellet radius can alternatively be described by regular diffusion with the modified activation law. The increased fuel porosity results in enhanced effective diffusion of FP and can be described by weakened diffusion dependence on the temperature characterized by the power index $\alpha$ smaller than 1 .

\section{Conclusions}

The diffusion of FP in nuclear fuel is influenced by the fuel microstructure - fuel grains, defects, and porosity in the $\mathrm{UO}_{2}$ fuel matrix. We have taken into account the effect of nuclear fuel grain boundary bubbles introducing the periodical modulation function of the FP diffusion coefficient. The numerical solution of the diffusion equation with the modified diffusion coefficient shows that the FP migration is qualitatively well approximated. Our model predicts the enhanced FP diffusion with a modified diffusion coefficient as it is observed experimentally for medium and higher burnup fuel. Furthermore, we qualitatively reproduced the experimentally observed FP distribution profile in the fuel pellet. On the other hand, the effect of developed grain boundary structure can be characterized with the modified Arrhenius expression (Eq. (5)) of the diffusion coefficient. The power index $\alpha$ less than 1 in Eq. (5) weakens Arrhenius behaviour of the diffusion coefficient and indicates the enhanced diffusion of FP in the fuel matrix with developed porosity.

\section{References}

[1] B.J. Lewis and A. Husain, Modelling the activity of ${ }^{129} \mathrm{I}$ in the primary coolant of a CANDU reactor, J. Nucl. Mater. 312, 81-96 (2003).

[2] J.G. Degaltsev, N.N. Ponomaryov-Stepnoy, and V.F. Kuznetsov, Behaviour of the High Temperature Nuclear Fuel During Irradiation (Moscow, Energoatomizdat, 1987) [in Russian].

[3] L.O. Jernkvist, A.R. Massih, and J. In de Betou, Evaluation of fission product gas release and the impact of fuel microstructure at high burnup (EHPG Meeting, Storefjell, Gol, Norway, 2002).

[4] J.A. Turnbull, R.J. White, J.R. Findlay, F.A. Johnson, and A.J. Walter, The diffusion coefficients of gaseous and volatile species during the irradiation of uranium dioxide, J. Nucl. Mater. 107, 168-184 (1982).

[5] R.J. White, The fractal nature of the surface of uranium dioxide: a resolution of the short-lived/stable gas release dichotomy, J. Nucl. Mater. 295, 133-148 (2001).

[6] V. Remeikis, L. Juodis, G. Trinkunas, G. Kamuntavicius, and R. Kalinauskas, On the radionuclide release mechanisms in irradiated nuclear fuel, Environmental Chem. Phys. 25, 164-170 (2003).

[7] W.H. Hocking, R.A. Verrall, and I.J. Muir, Migration behaviour of iodine in nuclear fuel, J. Nucl. Mater. 294, 45-52 (2001).

[8] P. Blair, A. Romano, Ch. Hellwig, and R. Chawla, Calculations on fission gas behaviour in the high burnup structure, J. Nucl. Mater. 350, 232-239 (2006). 


\title{
BRANDUOLINIO KURO MIKROSTRUKTŪROS ITAKOS DALIJIMOSI PRODUKTU SMELKIMUISI MODELIS
}

\author{
G. Stankūnas ${ }^{\text {a }}$, G. Kamuntavičius ${ }^{\text {a }}$, L. Juodis ${ }^{\text {b }}$, G. Trinkūnas ${ }^{\text {b }}$, V. Remeikis ${ }^{\text {b }}$ \\ ${ }^{a}$ Vytauto Didžiojo universitetas, Kaunas, Lietuva

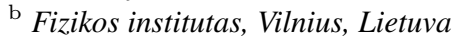

\section{Santrauka}

Dujinių branduolinio kuro (BK) dalijimosi produktų (DP) išsiskyrimui iš $\mathrm{BK}$ tablečių $\mathrm{UO}_{2}$ matricos žymią įtaką daro $\mathrm{BK}$ mikrostruktūros dariniai - granulès, DP ertmès granulèse ir tarp jų bei $\mathrm{UO}_{2}$ matricos defektai. Pastebèta, kad vidutinio ir didelio išdegimo BK ertmès pagreitina DP smelkimąsi, veikdamos kaip poringi kuro dariniai, lengvinantys DP išsiskyrimą. Siūloma atsižvelgti ị BK tablečiu mikrostruktūros poringumą, moduliuojant DP difuzijos koeficientą periodine funkcija. Tokia radialioji difuzijos koeficiento priklausomybe siejama su BK dariniais - tarpgranulinėmis ertmėmis ir granulių kraštais, egzistuojančiais šviežiame ir panaudotame BK. Skaitmeninis DP BK tableteje difuzijos lygties sprendimas parodè, kad DP iš BK matricos smelkiasi greičiau lyginant su atveju, kai i kuro mikrostruktūrą neatsižvelgiama. Tai siejama su greitesne DP difuzija BK tarpgranulinèse ertmėse, kai $\mathrm{BK}$ išdegimas yra vidutinis ir didelis $(>30 \mathrm{MW} \mathrm{d} / \mathrm{kg} \mathrm{U})$. Rasta, kad DP koncentracijos radialusis pasiskirstymas BK tableteje yra kokybiškai panašus i pateikiamus literatūroje. Modeliuojant dalijimosi produktų smelkimąsi i branduolinị kurą, išaiškinta, kad moduliuota difuzija atitinka iprasto difuzijos koeficiento temperatūrinès priklausomybès nukrypimą nuo aktyvacinio désnio. 